E-ISSN : 2549-6581

DOI: 10.21776/ub.JOIM.2019.003.03.1

Artikel Hasil Penelitian

Diterima : 2 Juli 2018

Direview : 16 Oktober 2019

Dimuat : Desember 2019 - Maret 2020
OPEN ACCESS

Journal of Issues in Midwifer

\title{
Hubungan Praktik Pemberian Makanan Pendamping Air Susu Ibu (Usia Awal Pemberian, Konsistensi, Jumlah dan Frekuensi) Dengan Status Gizi Bayi 7-23 Bulan
}

\author{
Winny Kirana Hasanah ${ }^{1 *}$, Ni Luh Putu Herli Mastuti ${ }^{2}$, Mega Ulfah ${ }^{2}$ \\ 1*) Program Studi S1 Kebidanan, Fakultas Kedokteran, Universitas Brawijaya, Email: \\ winnykirana@gmail.com, Tlp : +6285258725509 \\ ${ }^{2}$ Program Studi S1 Kebidanan, Fakultas Kedokteran, Universitas Brawijaya, Email: \\ niluhputuherlimastuti@gmail.com; megaulfah88@gmail.com
}

\begin{abstract}
The first a thousand days of life since intrauterine until two years old is an important period in determining a person's health. The adequate nutrition during this period can support the growth and development of children optimally. When the baby's needs cannot be fulfilled with breast milk alone, complementary feeding needs to be given to infants from the age of 6 months. Parents need to pay attention to the complementary feeding for the babies to have good nutritional status. The complementary feeding should be adjusted to the infant age stage, in terms of the initial age of giving, consistency, amount and frequency. The purpose of this research is to know the correlation between the practice of complementary feeding (initial age of giving, consistency, amount and frequency) and nutritional status of baby 7-23 months in Tajinan Village, Tajinan District, Malang. This study uses cross sectional design. The total sample of this research were 54 babies which were taken with proportional random sampling technique. The data were analyzed using Likelihood Ratio statistic test. The results obtained that there is a significant correlation between nutritional status of baby with the initial age of complementary feeding $(p=0,001)$, consistency of complementary feeding $(p=0,001)$, the amount of complementary feeding $(p=0,000)$ and frequency of complementary feeding $(p=0,011)$. The conclusion of this research is there is a correlation between the practice of complementary feeding with nutritional status of baby 7-23 months in Tajinan Village, Tajinan District, Malang.
\end{abstract}

Key words: initial age of complementary feeding, consistency of complementary feeding, amount of complementary feeding, frequency of complementary feeding, nutritional status.

\section{ABSTRAK}

Periode seribu hari awal kehidupan manusia sejak dalam kandungan hingga usia dua tahun merupakan periode penting dalam menentukan kesehatan seseorang. Pemenuhan nutrisi yang adekuat selama masa tersebut dapat mendukung pertumbuhan dan perkembangan anak secara optimal. Pada saat kebutuhan bayi tidak dapat tercukupi dengan ASI saja, maka Makanan Pendamping Air Susu Ibu (MP-ASI) perlu diberikan kepada bayi mulai usia 6 bulan. Orangtua perlu memperhatikan pemberian MP-ASI agar bayi memiliki status gizi yang baik. Pemberian MP-ASI harus disesuaikan dengan 
tahapan usia bayi, ditinjau dari usia awal pemberian, konsistensi, jumlah dan frekuensi. Tujuan dari penelitian ini untuk mengetahui adanya hubungan antara praktik pemberian MP-ASI (usia awal pemberian, konsistensi, jumlah dan frekuensi) dengan status gizi bayi pada usia 7 bulan sampai dengan 23 bulan di Desa Tajinan Kecamatan Tajinan Kabupaten Malang. Penelitian ini menggunakan desain cross sectional. Sampel penelitian berjumlah 54 orang yang diambil dengan teknik proportional random sampling. Data dianalisis dengan uji statistik Likelihood Ratio. Hasil yang diperoleh yaitu terdapat hubungan yang bermakna antara status gizi bayi dengan usia awal pemberian $(p=0,001)$, konsistensi MP-ASI $(p=0,001)$, jumlah pemberian MP-ASI $(p=0,000)$ dan frekuensi pemberian MP-ASI $(p=0,011)$. Kesimpulan dari penelitian ini adalah terdapat hubungan bermakna antara praktik pemberian Makanan Pendamping Air Susu Ibu (MP-ASI) dengan status gizi pada bayi yang berusia antara 7 hingga 23 bulan di Desa Tajinan Kecamatan Tajinan Kabupaten Malang.

Kata kunci: usia awal pemberian MP-ASI, konsistensi MP-ASI, jumlah MP-ASI, frekuensi MP-ASI, status gizi

`Korespondensi: Winny Kirana Hasanah. Surel: winnykirana@gmail.com

\section{PENDAHULUAN}

Seribu awal kehidupan manusia dimulai saat bayi dalam kandungan hingga bayi usia dua tahun. Periode tersebut penting sehingga membutuhkan pemenuhan nutrisi yang adekuat guna mendukung pertumbuhan, perkembangan dan kesehatan bayi secara optimal ${ }^{1}$.

Di negara berkembang, malnutrisi masih menjadi penyumbang angka morbiditas, mortalitas dan menghambat perkembangan neurologi pada anak. Sekitar 200 juta anak gagal mencapai pertumbuhan dan perkembangan potensialnya. Hal ini disebabkan karena kurangnya asupan nutrisi, pengaruh penyakit infeksi, lingkungan dan sanitasi yang buruk serta kekerasan sosial. Saat ini, hal yang dihadapi pada era modern tidak hanya masalah gizi kurang pada anak, tetapi juga permasalahan gizi lebih².

Ketika ASI saja sudah tidak dapat mencukupi kebutuhan nutrisi untuk pertumbuhan dan perkembangan bayi, maka diperlukan makanan pendamping untuk menunjang kebutuhan gizinya ${ }^{3}$. Sebelum tahun 2001, WHO merekomendasikan pemberian ASI eksklusif hingga usia 4 bulan dan pemberian MP-ASI dimulai saat usia 4 bulan. Kemudian, tahun 2002 WHO melakukan telaah untuk mengevaluasi perbedaan pemberian ASI eksklusif 4 bulan versus 6 bulan dan didapatkan hasil bahwa tidak ada studi yang menunjukkan pemberian ASI eksklusif 6 bulan memberikan dampak gangguan pertumbuhan dalam hal berat badan maupun panjang badan bayi ${ }^{4}$. Oleh karena itu, saat ini WHO merekomendasikan pemberian ASI eksklusif sampai usia 6 bulan dan pemberian MP-ASI dimulai pada usia 6 bulan (180 hari) yaitu ketika perkembangan bayi sudah siap untuk menerima makanan selain $\mathrm{ASI}^{5}$.

Saat ini masih banyak masyarakat yang memberikan makanan lain sebelum bayi berusia 6 bulan karena kebiasaan lama yang masih dipatuhi dan persepsi ibu bahwa anak rewel jika tidak diberikan makanan. Hal ini juga dapat terjadi karena pengaruh dari keluarga maupun orang-orang di 
sekitar ${ }^{6}$. Pengenalan MP-ASI harus tepat waktu serta mengandung nutrisi yang cukup untuk memenuhi asupan gizi sesuai umur bayi. Makanan tersebut harus mengandung mikronutrien dan vitamin yang dibutuhkan untuk pertumbuhan dan perkembangan kognitif bayi ${ }^{7}$.

$$
\text { Pemberian MP-ASI yang }
$$

tidak sesuai pada bayi dapat mengakibatkan terjadinya malnutrisi, meningkatkan risiko penyakit infeksi serta menghambat perkembangan kognitif anak. Ketidaksesuaian pemberian MP-ASI tersebut meliputi pemberian makanan pada usia yang terlalu dini atau terlambat, kandungan nutrisi pada makanan pendamping yang kurang serta perilaku kebersihan yang buruk ${ }^{7}$.

Pada tahun 2013, prevalensi status gizi kurang-buruk di Indonesia dengan indikator BB/U sebesar 19,6\%. Angka tersebut meningkat sebesar 1,7\% jika dibandingkan prevalensi tahun 2010 sebesar $17,9 \%$. Sedangkan prevalensi status gizi bayi kurussangat kurus berdasarkan indikator $\mathrm{BB} / \mathrm{TB}$ mengalami penurunan sebesar $1,2 \%$ dari tahun $2010 \mathrm{ke}$ tahun $2013^{8}$. Dari data Riskesdas 2013, prevalensi bayi kurus-sangat kurus sebesar $13,3 \%$ pada tahun 2010 dan $12,1 \%$ pada tahun $2013^{8}$. Meskipun angka tersebut menurun, namun prevalensi sebesar 12,1\% termasuk masalah serius ${ }^{9}$.

Menurut Dinas Kesehatan Provinsi Jawa Timur, angka status gizi kurang dan buruk tahun 2013 adalah $12,1 \%$, meningkat menjadi $12,3 \%$ pada tahun $2014^{10}$. Data dari Dinas Kesehatan Kabupaten Malang, ditemukan sebanyak 5,08\% kasus bayi gizi buruk dan sebesar $0,67 \%$ bayi gizi kurang di tahun
2016. Di Kecamatan Tajinan, prevalensi gizi balita kurang-buruk dan balita kurus-sangat kurus mengalami peningkatan dari tahun 2014-2016. Angka status gizi kurussangat kurus berdasarkan indikator BB/TB tahun 2014-2016 secara berturut-turut sebesar 1,73\%, 2,24\% dan $2,50 \%$. Angka status gizi kurang-buruk tahun 2014-2016 sebesar 9,18\%, 9,58\% dan $10,18 \%{ }^{11}$.

Dari hasil studi pendahuluan, Desa Tajinan termasuk dalam 3 besar tertinggi di Kecamatan Tajinan yang memiliki balita dengan status gizi kurang-buruk serta balita kurus-sangat kurus pada tahun 2016. Berdasarkan uraian tersebut, peneliti tertarik melakukan penelitian "Hubungan Praktik Pemberian MPASI (Usia Awal Pemberian, Konsistensi, Jumlah dan Frekuensi) dengan Status Gizi Bayi Usia 7-23 Bulan di Desa Tajinan Kecamatan Tajinan Kabupaten Malang".

\section{METODE PENELITIAN Rancangan/Desain Penelitian}

Penelitian ini menggunakan desain penelitian cross sectional dengan variabel bebas yaitu praktik pemberian MP-ASI ditinjau dari usia awal pemberian, konsistensi, jumlah serta frekuensi dan variabel terikat yaitu status gizi bayi usia 7-23 bulan.

\section{Sumber Data}

Sumber data dalam penelitian ini berasal dari data primer yang diperoleh langsung dari responden melalui pengisian lembar kuisioner praktik pemberian MP-ASI dan pengukuran antropometri berat badan serta panjang badan bayi. Sedangkan untuk data sekunder diperoleh dari buku Kesehatan Ibu dan Anak (KIA) untuk melihat 
riwayat BBLR dan kelahiran prematur.

\section{Sasaran Penelitian}

Populasi dalam penelitian ini adalah seluruh bayi yang berusia 7 23 bulan di Desa Tajinan Kecamatan Tajinan Kabupaten Malang yang berjumlah 116 bayi.

Sampel yang diteliti adalah bayi yang berusia 7-23 bulan di Desa Tajinan Kecamatan Tajinan Kabupaten Malang yang memenuhi kriteria inklusi eksklusi. Kriteria inklusi dalam penelitian ini yaitu bayi usia 7-23 bulan dengan pemberian MP-ASI, dalam keadaan sehat saat dilakukan penelitian, dan ibunya bersedia untuk menandatangani informed consent serta mengizinkan bayi untuk menjadi responden dalam penelitian. Sedangkan kriteria eksklusi yaitu bayi yang memiliki riwayat BBLR, riwayat kelahiran prematur dan bayi dengan kelainan bawaan seperti penyakit jantung bawaan, labiopalatoshcizis, atau penyakit Hirschprung.

Sampel diambil

menggunakan teknik proportional random sampling. Perhitungan sampel menggunakan rumus Slovin, sehingga diperoleh 54 sampel penelitian.

\section{Pengembangan Instrumen dan Teknik Pengumpulan Data}

Peneliti menggunakan beberapa instrumen penelitian meliputi lembar kuisioner praktik pemberian MP-ASI, timbangan bayi dan timbangan berdiri untuk mengukur berat badan bayi, infantometer dan microtoise untuk mengukur tinggi badan bayi serta grafik WHO Child Growth Standards 2005 untuk menilai status gizi anak menggunakan indikator berat badan menurut tinggi badan.

\section{Teknik Analisis Data}

Analisis data pada penelitian ini menggunakan uji statistik Likelihood Ratio untuk mengetahui hubungan dari dua variabel bermakna atau tidak dengan tingkat kepercayaan $\alpha \leq 0,05$. Data akan diolah menggunakan program SPSS for windows.

Penelitian ini telah mendapatkan ethical clearance oleh komisi etik penelitian kesehatan Fakultas Kedokteran Universitas Brawijaya Malang No. 296/EC/KEPK-S1-KB/08/2017.

HASIL PENELITIAN

Analisis Univariat

1. Karakteristik Ibu

Tabel 1. Distribusi Karakteristik Ibu di Desa Tajinan Kabupaten Malang

\begin{tabular}{lcc}
\hline \multicolumn{1}{c}{ Karakteristik Ibu } & $\mathbf{N}$ & $\%$ \\
\hline Usia (tahun) & & \\
$\leq 19$ & 2 & 3,7 \\
$20-29$ & 28 & 51,9 \\
$30-39$ & 19 & 35,2 \\
$\geq 40$ & 5 & 9,3 \\
\hline Pekerjaan & & \\
IRT & 40 & 74,1 \\
Buruh/Petani & 4 & 7,4 \\
Wirausaha & 3 & 5,6 \\
PNS & 1 & 1,9 \\
Swasta & 2 & 3,7 \\
Lain-lain & 4 & 7,4 \\
\hline Paritas & & \\
1 & 25 & 46,3 \\
2 & 21 & 38,9 \\
3 & 7 & 13,0 \\
4 & 1 & 1,9 \\
\hline Pendidikan & & \\
SD & 19 & 35,2 \\
SMP & 11 & 20,4 \\
SMA & 16 & 29,6 \\
Perguruan Tinggi & 8 & 14,8 \\
\hline
\end{tabular}




\begin{tabular}{lcc}
\hline Penghasilan (bulan) & & \\
$<1.500 .000$ & 26 & 48,1 \\
$<1.500 .000-2.500 .000$ & 18 & 33,3 \\
$2.500 .000-3.500 .000$ & 7 & 13,0 \\
$>3.500 .000$ & 3 & 5,6 \\
\hline
\end{tabular}

Pada tabel 1 tentang karakteristik ibu diperoleh hasil bahwa sebagian besar ibu dari bayi yang menjadi responden dalam penelitian ini berusia 20-29 tahun sebanyak $51,9 \%$ (28 orang). Mayoritas ibu memiliki pekerjaan sebagai lbu Rumah Tangga (IRT) sebanyak $74,1 \% \quad$ (40 orang). Sebagian besar ibu di Desa Tajinan Kecamatan Tajinan Kabupaten Malang memiliki paritas 1 yaitu sebesar 46,3\% (25 orang). Mayoritas ibu memiliki pendidikan terakhir Sekolah Dasar (SD) sebanyak $35,2 \% \quad$ (19 orang). Penghasilan keluarga per bulan menurut tabel 1 diketahui bahwa sebagian besar keluarga di Desa Tajinan Kabupaten Malang memiliki penghasilan per bulan yaitu kurang dari $\mathrm{Rp} 1.500 .000,00$ dengan persentase sebesar 48,1\% (26 orang).

\section{Karakteristik Bayi}

\section{Tabel 2. Distribusi Karakteristik} Bayi Usia 7-23 Bulan di Desa Tajinan Kabupaten Malang

\begin{tabular}{lcc}
\hline Karakteristik Bayi & $\mathbf{N}$ & $\%$ \\
\hline Usia (bulan) & & \\
$7-8$ & 8 & 14,8 \\
$9-11$ & 12 & 22,2 \\
$12-23$ & 34 & 63,0 \\
\hline Jenis Kelamin & & \\
$\quad$ Laki-laki & 34 & 63,0 \\
$\quad$ Perempuan & 20 & 37,0 \\
\hline
\end{tabular}

Pada tabel 2 dapat diketahui bahwa dari 54 bayi yang termasuk dalam responden penelitian mayoritas berada pada kelompok usia 12-23 bulan yaitu sebesar 63,0\% (34 bayi). Berdasarkan data pada tabel tersebut diperoleh bahwa sebagian besar responden berjenis kelamin laki-laki sebesar 63,0\% (34 bayi).

\section{Praktik Pemberian MP-ASI}

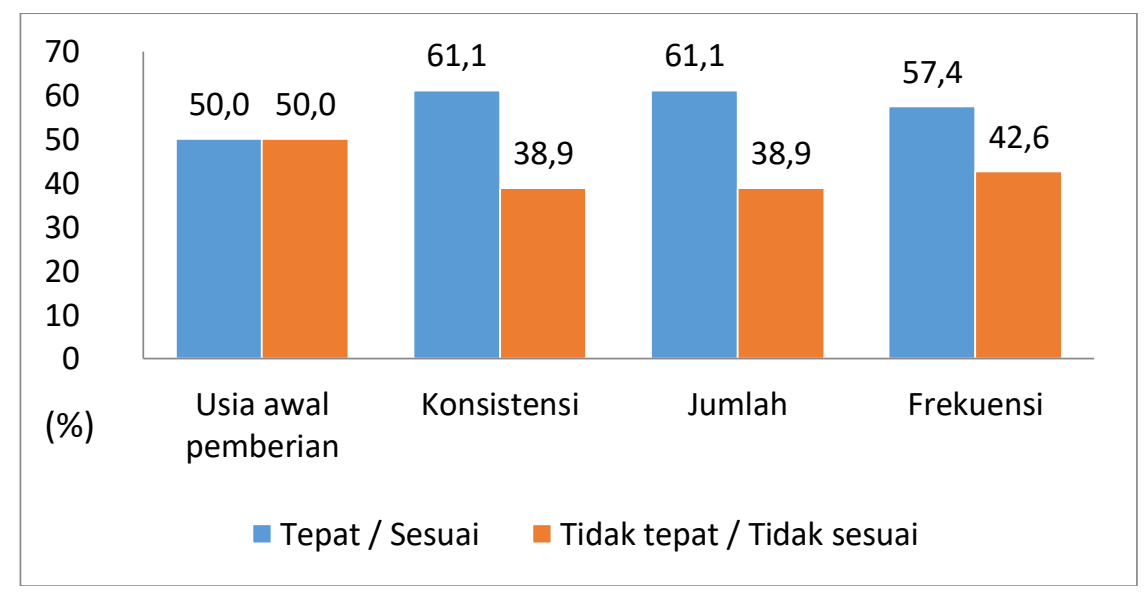

Gambar 1. Data Praktik Pemberian MP-ASI (Usia Awal Pemberian, Konsistensi, Jumlah dan Frekuensi). 
Usia awal pemberian MP-ASI dikelompokkan menjadi tidak tepat ( $<6$ bulan atau $>6$ bulan) dan tepat (6 bulan). Pada gambar 1 dapat dilihat bahwa persentase antara tepat dan tidak tepat memiliki angka yang sama yaitu masing-masing sebesar $50,0 \%$ (28 bayi).

Konsistensi pemberian MPASI dikelompokkan menjadi sesuai dan tidak sesuai dengan usia bayi. Sebagian besar bayi mendapatkan MP-ASI dengan konsistensi yang sesuai sebesar $61,1 \%$ (33 bayi) sedangkan MP-ASI dengan konsistensi yang tidak sesuai sebesar $38,9 \%$ ( 21 bayi).
Jumlah pemberian MP-ASI dikelompokkan menjadi sesuai dan tidak sesuai usia bayi. Mayoritas bayi diberikan MP-ASI dengan jumlah tiap kali makan yang sesuai sebesar $61,1 \%$ (33 bayi) dan sebesar 38,9\% (21 bayi) diberikan MP-ASI dengan jumlah yang tidak sesuai.

Frekuensi pemberian MP-ASI diperoleh hasil bahwa sebagian bayi mendapatkan MP-ASI dengan frekuensi harian yang sesuai dengan usianya yaitu sebesar $57,4 \%$ (31 bayi) dan sebesar $42,6 \%$ (23 bayi) mendapatkan MP-ASI dengan frekuensi tidak sesuai.

\section{Status Gizi Bayi}

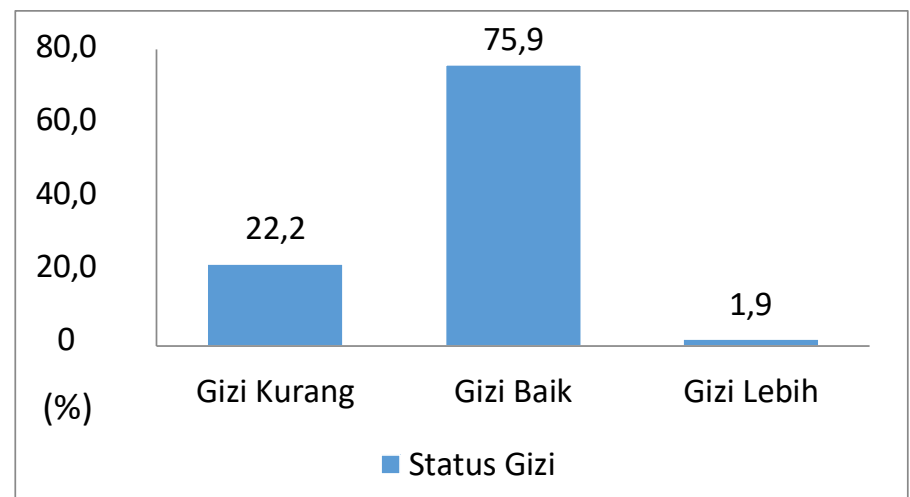

\section{Gambar 2. Distribusi Status Gizi pada Bayi (7 hingga 23 bulan) di Desa Tajinan Kecamatan Tajinan Kabupaten Malang}

Berdasarkan gambar 2 tentang distribusi status gizi bayi pada bayi ( 7 hingga 23 bulan) di Desa Tajinan, sebagian besar memiliki status gizi baik sebesar
$75,9 \%$ (41 bayi). Bayi yang memiliki status gizi kurang sebesar 22,2\% (12 bayi) dan status gizi lebih sebesar $\quad 1,9 \% \quad(1 \quad$ bayi). 


\section{Analisis Bivariat}

Tabel 3. Hubungan Praktik Pemberian MP-ASI (Usia Awal Pemberian, Konsistensi, Jumlah dan Frekuensi) dengan Status Gizi Bayi Usia 7-23

\section{Bulan}

\begin{tabular}{|c|c|c|c|c|c|c|c|c|c|c|}
\hline \multirow{3}{*}{ Variab } & & \multicolumn{6}{|c|}{ Status Gizi } & \multicolumn{3}{|c|}{ Total } \\
\hline & & \multicolumn{2}{|c|}{$\begin{array}{c}\text { Gizi } \\
\text { Kurang }\end{array}$} & \multicolumn{2}{|c|}{ Gizi Baik } & \multicolumn{2}{|c|}{$\begin{array}{l}\text { Gizi } \\
\text { Lebih }\end{array}$} & \multirow[t]{2}{*}{$\mathbf{N}$} & \multirow[t]{2}{*}{$\%$} & \multirow{2}{*}{$\begin{array}{c}\mathbf{P} \\
\text { Value }\end{array}$} \\
\hline & & $\mathbf{n}$ & $\%$ & $\mathbf{n}$ & $\%$ & $\mathbf{n}$ & $\%$ & & & \\
\hline \multirow{2}{*}{$\begin{array}{l}\text { Usia Awal } \\
\text { Pemberian }\end{array}$} & $\begin{array}{l}\text { Tidak } \\
\text { Tepat }\end{array}$ & 11 & 20,4 & 15 & 27,8 & 1 & 1,9 & 27 & 50,0 & \multirow{2}{*}{0,001} \\
\hline & Tepat & 1 & 1,9 & 26 & 48,1 & 0 & 0 & 27 & 50,0 & \\
\hline \multirow[t]{2}{*}{ Konsistensi } & $\begin{array}{l}\text { Tidak } \\
\text { Sesuai }\end{array}$ & 10 & 18,5 & 11 & 20,4 & 0 & 0 & 21 & 38,9 & \multirow[t]{2}{*}{0,001} \\
\hline & Sesuai & 2 & 3,7 & 30 & 55,6 & 1 & 1,9 & 33 & 61,1 & \\
\hline \multirow[t]{2}{*}{ Jumlah } & $\begin{array}{l}\text { Tidak } \\
\text { Sesuai }\end{array}$ & 10 & 18,5 & 10 & 18,5 & 1 & 1,9 & 21 & 38,9 & \multirow[t]{2}{*}{0,000} \\
\hline & Sesuai & 2 & 3,7 & 31 & 57,4 & 0 & 0 & 33 & 61,1 & \\
\hline \multirow[t]{2}{*}{ Frekuensi } & $\begin{array}{l}\text { Tidak } \\
\text { Sesuai }\end{array}$ & 9 & 16,7 & 13 & 24,1 & 1 & 1,9 & 23 & 42,6 & \multirow[t]{2}{*}{0,011} \\
\hline & Sesuai & 3 & 5,6 & 28 & 51,9 & 0 & 0 & 31 & 57,4 & \\
\hline
\end{tabular}

*Uji Statistik Likelihood Ratio

Berdasarkan tabel 3 uji statistik yang digunakan untuk menganalisis variabel usia awal pemberian makanan pendamping air susu ibu dengan dilihat status gizinya, menggunakan Uji Likelihood Ratio. Hasil analisis antara kedua variabel tersebut didapatkan nilai $p$ sebesar 0,001 $(p<0,05)$. Maka dapat disimpulkan terdapat hubungan yang signifikan pada usia awal pemberian makanan pendamping air susu ibu dengan keadaan status gizi pada bayi yang berusia antara 7 sampai dengan 23 bulan.

Variabel konsistensi pemberian makanan pendamping air susu ibu dan status gizi bayi dianalisis menggunakan uji statistik Likelihood Ratio. Menurut tabel 3, hasil analisis antara kedua variabel tersebut diperoleh nilai $\mathrm{p}$ adalah $0,001 \quad(p<0,05)$. Kesimpulannya, terdapat hubungan bermakna pada variabel konsistensi pemberian makanan pendamping air susu ibu dengan status gizi pada usia 7 bulan sampai dengan 23 bulan.
Uji statistik Likelihood Ratio digunakan untuk menganalisis variabel jumlah pemberian makanan pendamping air susu ibu dan status gizi. Analisis hasil pada kedua variabel tersebut diperoleh $p=0,000$ $(p<0,05)$. Kesimpulan yang dapat diambil terdapat hubungan yang signifikan dari jumlah pemberian makanan pendamping air susu ibu dengan status gizi bayi usia 7-23 bulan.

Variabel frekuensi pemberian makanan pendamping air susu ibu dengan status gizi bayi dianalisis dengan uji statistik Likelihood Ratio. Hasil analisis antara kedua variabel tersebut diperoleh $p=0,011(p<0,05)$. Kesimpulannya terdapat hubungan frekuensi pemberian makanan pendamping air susu ibu dengan status gizi bayi usia 7-23 bulan

\section{PEMBAHASAN \\ Usia Awal Pemberian MP-ASI dengan Status Gizi}

Pada gambar 3. terlihat bahwa prosentase ibu di Desa 
Tajinan yang memberikan MP-ASI pada usia tepat (6 bulan) dan ibu yang mulai memberikan MP-ASI pada usia yang tidak tepat $(<6$ bulan atau >6) masing-masing memiliki prosentase yang sama yaitu sebesar $50 \%$. Bayi mulai membutuhkan makanan selain air susu ibu saat usia 6 bulan. Hal ini karena pada waktu ini terdapat kesenjangan nutrisi dan energi yang harus dipenuhi dengan makanan pendamping asi.

Penelitian ini menyebutkan bahwa ibu yang memberikan MPASI kepada bayi di usia awal pemberian yang tidak tepat memiliki anak dengan status gizi baik $(27,8 \%)$, status gizi kurang $(20,4 \%)$ dan satu orang bayi dengan status gizi lebih (1,9\%). Sedangkan ibu yang memberikan MP-ASI di usia yang tepat cenderung memiliki bayi dengan status gizi baik $(48,1 \%)$ dan satu orang bayi dengan status gizi kurang $(1,9 \%)$.

Air Susu Ibu (ASI) adalah makanan bernutrisi serta berenergi tinggi yang mudah dicerna oleh bayi. Imunitas yang didapat bayi lebih besar jika diberikan ASI eksklusif karena ASI mengandung lebih dari 50 faktor imunitas. Bayi yang paling baik kekebalannya adalah bayi yang mendapat ASI eksklusif selama 6 bulan. Pemberian ASI secara eksklusif tanpa makanan selama usia 6 bulan dapat mengurangi kejadian diare dan penyakit pernafasan jika dibandingkan dengan yang diberikan ASI eksklusif selama 3 atau 4 bulan. Sedangkan pemberian MP-ASI yang terlambat akan menimbulkan gangguan pertumbuhan, defisiensi mikronutrien, dan terjadi penyakit infeksi ${ }^{12,15}$.
Sejalan dengan Subandary (2014) dalam penelitiannya mengemukakan bahwa anak yang mendapat MP-ASI di usia kurang dari 6 bulan berisiko memiliki status gizi kurang sebesar 3,509 kali. Hal tersebut disebabkan karena ibu bekerja, ASI ibu tidak keluar dan ibu pendapat bahwa anak menangis jika tidak diberikan makanan ${ }^{13}$.

Sama halnya dengan penelitian yang dilakukan oleh Nurfaizah, anak yang diberikan MPASI pada usia kurang dari 6 bulan memiliki status gizi kurus dan status gizi sangat kurus. Status gizi kurus juga didapat pada anak yang diberi makanan pendamping setelah usia 6 bulan ${ }^{14}$.

$$
\text { Pemberian MP-ASI yang }
$$

terlalu dini dapat menggantikan peran ASI untuk memenuhi zat gizi pada anak sehingga anak tidak memperoleh gizi yang optimal dan hal tersebut meningkatkan risiko alergi ${ }^{19}$. Sedangkan pemberian makanan pendamping air susu ibu yang terlambat berdampak pada kondisi status gizi anak. Hal ini disebabkan karena saat bayi menginjak 6 bulan, ASI hanya memberikan sumbangan gizi sebesar $40-50 \%$. Terlambat dalam memberikan MP-ASI mengakibatkan pertumbuhan dan perkembangan anak menjadi lebih lambat. Kebutuhan akan zat besi, vitamin $A$, vitamin $C$, kalsium, fluor dan protein juga meningkat saat bayi berusia enam bulan sehingga bayi memerlukan makanan pendamping air susu ibu ${ }^{16}$.

\section{Konsistensi MP-ASI dengan Status Gizi}

Penelitian ini menunjukkan bahwa ibu yang memberikan MPASI dengan konsistensi yang tidak 
sesuai kepada bayi, memiliki bayi dengan status gizi baik $(20,4 \%)$ dan status gizi kurang (18,5\%). Sedangkan ibu yang memberikan makanan pendamping ASI dengan konsistensi yang sesuai, cenderung memiliki bayi dengan status gizi baik $(55,6 \%)$, beberapa bayi dengan status gizi kurang $(3,7 \%)$ dan satu orang bayi dengan status gizi lebih $(1,9 \%)$.

Larasati dalam penelitiannnya mendukung bahwa ada hubungan yang kuat pada variabel konsistensi makanan pendamping dan status gizi anak umur 6 hingga 23 bulan ${ }^{18}$.

Saat pertama kali MP-ASI diperkenalkan, bayi memerlukan adaptasi dengan makanan yang baru karena sebelumnya hanya mengonsumsi ASI saja. Oleh sebab itu, konsistensi MP-ASI yang diberikan kepada bayi perlu tahapan yang sesuai dengan perkembangan organ pencernaan bayi. Pada tahap awal, bayi dapat diberikan MP-ASI dengan konsistensi agak cair yang kemudian dikentalkan secara bertahap ${ }^{17}$. Kekentalan MP-ASI yang diberikan akan menentukan kebutuhan gizi bayi terpenuhi atau tidak. Pemberian MP-ASI yang cukup kental dapat memberikan energi lebih banyak dibanding bubur MP-ASI yang terlalu encer ${ }^{19}$.

Pengenalan MP-ASI yang sesuai dengan tahapan usia bayi bertujuan untuk mengajarkan keterampilan mengunyah terutama pada fase kritis yaitu saat usia 6-9 bulan. Tahapan konsistensi MP-ASI dimulai makanan lumat untuk bayi usia $6-8$ bulan. Kemudian makanan lembek atau dicincang yang mudah ditelan untuk bayi 9-11 bulan, dan makanan keluarga seperti yang dimakan oleh orang dewasa untuk bayi usia 12-23 bulan Apabila bayi diberikan MP-ASI dengan tahapan yang tidak sesuai misalnya diberikan MP-ASI dengan konsistensi agak kasar maka akan menyebakan bayi mudah sakit perut karena perkembangan otot lambung kurang sempurna, sebaliknya makanan yang cenderung encer memiliki kandungan energi yang rendah ${ }^{16}$.

\section{Jumlah Pemberian MP-ASI dengan Status Gizi}

Hasil analisis menunjukkan ada hubungan yang signifikan antara jumlah pemberian makanan pendamping air susu ibu pada bayi yang berusia 7 bulan sampai dengan 23 bulan dengan keadaan status gizi (nilai $p=0,000$ ( $p<$ $0,05)$ ). Ibu yang memberikan makanan pendamping ASI dengan jumlah yang tidak sesuai, memiliki bayi dengan status gizi kurang $(18,5 \%)$, bayi dengan status gizi baik $(18,5 \%)$ dan satu orang bayi dengan status gizi lebih (1,9\%). Sedangkan ibu yang memberikan MP-ASI kepada bayi dengan jumlah yang sesuai, cenderung memiliki bayi dengan status gizi baik $(57,4 \%)$ dan beberapa bayi dengan status gizi kurang $(3,7 \%)$. Jumlah MP-ASI yang sesuai untuk bayi usia 6-8 bulan adalah 2-3 sendok makan kemudian ditingkatkan hingga $1 / 2$ mangkok berukuran $250 \mathrm{ml}$, untuk bayi usia 9-11 bulan adalah $1 / 2$ sampai $3 / 4$ mangkok berukuran 250 $\mathrm{ml}$ dan untuk bayi usia $12-23$ bulan adalah $3 / 4$ hinggan 1 mangkok penuh berukuran $250 \mathrm{ml}$.

Sejalan dengan penelitian Subandary, bahwa anak diberikan porsi MP-ASI yang tidak sesuai, maka 3,902 kali berisiko mengalami keadaan status gizi yang kurang 
dibandingkan dengan anak yang mendapatkan makanan pendamping dengan porsi sesuai ${ }^{13}$. Penelitian Waliyo et al. juga menyatakan bahwa anak yang memperoleh makanan pendamping air susu ibu dengan jumlah yang kurang, mempunyai keadaan gizi kurus sebesar $95,6 \%^{20}$.

$$
\text { Jumlah }
$$

makanan

pendamping ASI kepada bayi perlu diperhatikan mengingat kapasitas lambung bayi yang masih sedikit. Dalam menentukan jumlah MP-ASI yang diberikan, respon bayi terhadap makanan dapat menjadi pertimbangan ibu untuk memberikan MP-ASI dengan jumlah bertahap yang disesuaikan dengan usia bayi ${ }^{17}$.

Periode pemberian Makanan Pendamping Air Susu Ibu (MP-ASI) merupakan masa rawan pertumbuhan anak sehingga anak berisiko tinggi untuk mengalami malnutrisi. Hal tersebut terjadi karena MP-ASI yang diberikan kepada anak memiliki jumlah yang terlalu sedikit dan kualitas nutrisi yang tidak adekuat. Porsi makanan yang dibutuhkan tergantung pada kecukupan energi yang terkandung dalam makanan. Kandungan energi dari MP-ASI berkisar antara 0,6 hingga $1,0 \mathrm{kkal}$ per gram. Apabila MP-ASI yang diberikan memiliki kecukupan energi yang lebih, maka jumlah MP-ASI yang sedikit dapat menutup kesenjangan energi, namun apabila MP-ASI dilarutkan dalam air, maka diperlukan jumlah MP-ASI dengan volume yang lebih banyak untuk memenuhi kebutuhan energi pada bayi ${ }^{12}$.

\section{Frekuensi Pemberian MP-ASI dengan Status Gizi \\ Berdasarkan \\ analisis}

hubungan frekuensi pemberian makanan pendamping air susu ibu dengan status gizi pada bayi, dapat diketahui bahwa ada hubungan yang signifikan dengan nilai $p 0,011$ $(p<0,05)$ antara frekuensi pemberian MP-ASI dengan status gizi bayi usia 7-23 bulan. Hasil penelitian menunjukkan bahwa ibu yang memberikan MP-ASI kepada bayi dengan frekuensi pemberian MPASI yang tidak sesuai, memiliki bayi dengan status gizi baik $(24,1 \%)$, status gizi kurang $(16,7 \%)$ dan satu orang bayi dengan status gizi lebih $(1,9 \%)$. Sedangkan ibu yang memberikan MP-ASI dengan frekuensi sesuai kepada bayi, cenderung memiliki bayi dengan status gizi baik $(51,9 \%)$ dan beberapa bayi dengan status gizi kurang $(5,6 \%)$. Pada bayi usia 6-8 bulan, frekuensi MP-ASI yang sesuai yaitu makanan utama 2-3 kali sehari dan makanan selingan 1-2 kali sehari, untuk bayi usia 9-23 bulan frekuensi makanan utama 3-4 kali sehari dengan makanan selingan yaitu 1-2 kali sehari.

Hal ini sejalan dengan penelitian Widyawati, menyatakan bahwa risiko status gizi kurus meningkat sejumlah 6,6 kali lipat jika bayi diberi MP-ASI dengan frekuensi kurang dari 3 kali dalam sehari ${ }^{21}$.

Waliyo et al. juga menyatakan hal yang sama bahwa anak yang mendapatkan frekuensi MP-ASI tidak baik yaitu kurang dari 2 kali sehari, sebanyak $80 \%$ memiliki status gizi kurus ${ }^{20}$.

Pemberian MP-ASI pada bayi dengan frekuensi yang tidak sesuai berisiko tinggi untuk jatuh dalam keadaan malnutrisi lanjutan dan 
berkontribusi terhadap tingginya prevalensi malnutrisi pada balita. Karena kapasitas lambung bayi masih terbatas (kira-kira 30 gram $/ \mathrm{kg}$ berat badan) atau sekitar $200 \mathrm{ml}$, maka untuk makanan lebih baik diberikan dengan frekuensi yang terbagi atas makanan utama (pagi, siang dan malam) serta makanan selingan di antara makanan utama, disertai dengan pemberian ASI atau susu formula sebanyak 2 hingga 3 kali sehari22.

\section{SIMPULAN}

Terdapat hubungan yang bermakna antara praktik pemberian MP-ASI (usia awal pemberian, konsistensi, jumlah dan frekuensi) dengan status gizi bayi usia 7-23 bulan di Desa Tajinan Kecamatan Tajinan Kabupaten Malang.

\section{DAFTAR PUSTAKA}

1. Achadi, E.L. Periode Kritis 1000 Hari Pertama Kehidupan dan Dampak Jangka Panjang terhadap Kesehatan dan Fungsinya. Makalah disajikan dalam Kursus Penyegar IImu Gizi, PERSAGI, Yogyakarta, 25 November. 2014.

2. Cusick, S and Georgieff, M.K. The First 1000 Days of Life: The Brain's Window of Opportunity, (Online). 2017 (www.unicefirc.org/article/958/, diakses 27 April 2017)

3. WHO, UNICEF. Strengthening Action to Improve Feeding of Infants and Young Children 6-23 Months of Age in Nutrition and Child Health Programmes, 6-9 October, Report of Proceeding, Geneva. 2008.

4. Sjarif D.R, Yuliarti K, Lestari E.D, Sidiarta I.G.L, Nasar S.S, et al., penyunting. Rekomendasi Praktik Pemberian Makan Berbasis Bukti pada Bayi dan Batita di Indonesia untuk Mencegah Malnutrisi. Jakarta: Ikatan Dokter Anak Indonesia. 2015.

5. WHO. Guiding Principles for Complementary Feeding of The Breastfed Child. Geneva: Department of Child and Adolescent Health and Development (CAH). 2003.

6. Mariani N.M., Hendarman H., Nita G.S., $\quad$ Faktor-faktor yang Berhubungan dengan Pemberian MP-ASI Dini di Wilayah Kerja UPTD Puskesmas Sindanglaut Kecamatan Lemahabang Kabupaten Cirebon, Jurnal Kesehatan, 2016; Vol. 7, No 3, 420-426

7. Arikpo D., Edet E.S., Chibuzor M.T., Odey F., Caldwell D.M., Educational Interventions for Improving Complementary Feeding Practices. Cochrane Database of Systematic Reviews, 2015, Issue 6. Art. No.: CD011768.

8. Riskesdas. Riset Kesehatan Dasar 2013. Badan Penelitian dan Pengembangan Kesehatan. Jakarta: Kementerian Kesehatan RI. 2013.

9. WHO. Nutrition Landscape Information System (NLIS) Country Profile Indicators Interpretation Guide. Geneva: WHO Press. 2010.

10. Dinas Kesehatan Provinsi Jawa Timur. Profil Kesehatan Provinsi Jawa Timur 2014. Surabaya. 2014.

11.Dinas Kesehatan Kabupaten Malang. Studi Pendahuluan. Kepanjen. 2017.

12.WHO. Infant and Young Child Feeding, Model Chapter for textbooks for medical students and aliied health professionals. Geneva: WHO Press. 2009.

13. Subandary, B.W. Hubungan Pola Pemberian ASI dan MP-ASI dengan Kejadian Status Gizi Kurang pada Anak Usia 6-24 Bulan di Desa Ubung Kecamatan Jonggat Kabupaten Lombok Tengah Nusa 
Tenggara Barat. Artikel IImiah. Tidak diterbitkan. Sekolah Tinggi IImu Kesehatan Ngudi Waluyo Ungaran. 2014.

14. Nurfaizah, S. Hubungan Lama Pemberian ASI dan Usia Pertama Pemberian MP-ASI dengan Status Gizi pada Anak Usia 12-24 Bulan di Desa Surodadi Kecamatan Gajah Kabupaten Demak. Artikel IImiah. Tidak diterbitkan. Sekolah Tinggi IImu Kesehatan Ngudi Waluyo Ungaran. 2016.

15. Hidayati, N.L. 1000 Hari Emas Pertama dan Persiapan Kehamilan sampai Batita. Yogyakarta: Rapha Publishing. 2014.

16. Febry A.B., Pujiastuti N., Fajar I. IImu Gizi untuk Praktisi Kesehatan. Yogyakarta: Graha IImu. 2013.

17. Fikawati S., Syafiq A., Karima K. Gizi Ibu dan Bayi. Jakarta: PT RajaGrafindo Persada. 2016

18. Larasati, W. Hubungan Antara Pola Pemberian Makanan Pendamping ASI (MP-ASI) dan Penyakit Infeksi Kaitannya dengan Status Gizi pada Bayi Umur 6-12 Bulan. Skripsi, Tidak diterbitkan, Fakultas IImu Keolahragaan Universitas Negeri Semarang. 2011.
19. Anggraini A.D., Markum M., Masoara S., Durjati S. Manajemen Makanan Pendamping Air Susu Ibu (MP-ASI). Jakarta: Perkumpulan Perinatologi Indonesia (PERINASIA). 2014.

20. Waliyo, E., Marlenywati., Nurseha., Hubungan Pengetahuan Gizi dan Pola Pemberian Makanan Pendamping ASI terhadap Status Gizi pada Umur 6-59 Bulan di Wilayah Kerja Puskesmas Selalong Kecamatan Sekadau Hilir Kabupaten Sekadau. Jurnal Kedokteran dan Kesehatan; 2017, Vol. 13, No. 1, 61-70

21. Widyawati., Febry F., Destriatania S., Analisis Pemberian MP-ASI dengan Status Gizi pada Anak Usia 12-24 Bulan di Wilayah Kerja Puskesmas Lesung Batu, Empat Lawang. Fakultas Kesehatan Masyarakat Universitas Sriwijaya, 2016, Vol. 7, No. 2

22. Nasar, S.S. "Makanan Pendamping ASI (MP-ASI)". Dalam: Suradi R., Hegar B., Partiwi I.G.A.N., Marzuki A.N.S., Ananta Y., penyunting. Indonesia Menyusui. Jakarta: Badan Penerbit

IDAI.

2010 